\title{
A importância do uso das Superfícies Elásticas no Processo de Treinamento Acrobático da Ginástica Artística Feminina
}

\author{
Isabella C. E. De Sordi (IC), Marco Antonio C. Bortoleto (PQ)
}

\begin{abstract}
Resumo
Esta pesquisa teve como objetivo analisar o emprego das Superfícies Elásticas ( $\mathrm{SpE}$ ) durante o processo de treinamento da Ginástica Artística Feminina (GAF), a partir de um estudo de caso no Clube Campineiro de Regatas e Natação (CCRN), de Campinas-SP. Trata-se de um estudo descritivo, realizado por meio de observação direta com registro em diário de campo (15 sessões) e entrevistas semiestruturadas junto a quatro das treinadoras. Embora o clube disponha de dois equipamentos específicos, seu uso é restrito e pouco integrado ao planejamento/periodização de treinamento, concentrando no preparo de elementos acrobáticos de solo e como auxiliar no processo de reabilitação de ginastas lesionadas.
\end{abstract}

Palavras Chave: Ginástica de Competição, Tecnologia, Treinamento Acrobático.

Introdução

Ao longo das últimas duas décadas os estudos científicos acerca da Ginástica Artística (GA), especialmente na vertente de alto rendimento, ressaltam a importância das $\mathrm{SpE}$ para $\mathrm{O}$ desenvolvimento e aperfeiçoamento técnico, como elemento motivador dos treinamentos, assim como para melhora da segurança. Embora treinadores, dirigentes e especialistas concordem a respeito da importância das SpE (BLANCO, 2007; NUNOMURA, TSUKAMOTO, 2009), são escassos os estudos científicos disponíveis acerca da temática. Neste sentido, acreditamos que este projeto adquire originalidade, especialmente quando descreve como as $\mathrm{SpE}$ vêm sendo empregadas no treinamento acrobático (BROCHADO e BROCHADO, 2005. p.99), mais especificamente no contexto da GAF do CCRN, equipe referente tanto em nível estadual e nacional.

\section{Resultados e Discussão}

Esta pesquisa consistiu num estudo descritivo, realizado por meio de observação direta com registro em diário de campo (15 sessões) e entrevistas semi-estruturadas junto a quatro treinadoras da equipe de GAF. Observamos que embora o CCRN tenha significativa tradição na modalidade, com resultados competitivos expressivos no âmbito estadual, seu ginásio de GAF dispõe de apenas dois equipamentos elásticos (Tumble Track e Trampolim Acrobático), além do praticável de solo. Constatamos que as $\mathrm{SpE}$ não são utilizadas com frequência (uma ou duas vezes por semana) e apenas as ginastas lesionadas usam quase todos os dias para substituir ou complementar o treino de solo. Quando usadas, as SpE dão suporte para o treino de elementos acrobáticos do solo, educativos para salto e paralela assimétricas, além dos saltos ginásticos. O Tumble Track é mais utilizado, especialmente para desenvolver sequências acrobáticas. Às sextas-feiras, as SpE são utilizadas também para fins recreativos. A falta de tempo, considerando que o treino tem duração de 3 horas e 45 minutos por dia (cinco vezes por semana) foi 0 principal argumento apresentado pelas treinadoras para explicar o pouco uso.

\section{Conclusões}

Parece-nos que a falta de formação especializada contribui para o escasso uso das $\mathrm{SpE}$, e que o alto custo desse tipo de tecnologia, muitas vezes importada, dificulta a aquisição de novos equipamentos. Constatamos ainda, que o uso dessas tecnologias é dificultado devido a necessidade de conciliar três equipes (distintas categorias) em um mesmo espaço de treino/período. De modo geral, embora se reconheça a contribuição das $\mathrm{SpE}$ no treinamento da GAF, aponta-se como necessário a aquisição de novos equipamentos e investimento em formação específica para as treinadoras, visando superar a cultura no uso das SpE nesse ginásio, que ainda é recente.

\section{Agradecimentos}

Ao CNPQ/PIBIC pelo suporte/bolsa; Ao CCRN por aceitar colaborar nesse projeto.

BLANCO, Raimundo. Aparelhos alternativos para o treinamento em GA. Anais do I Simposium Internacional de Ginástica Rítmica e Artística de Competição SIGARC. Rio de Janeiro, 2007

BROCHADO, F. E BROCHADO M. Fundamentos de Ginástica Artística e de Trampolins. Guanabara Koogan, Rio de Janeiro, 2005. NUNOMURA, M. TSUKAMOTO, M. H. C. (org.) Fundamentos das ginásticas. Editora Fontoura: Jundiaí, 2009. 